\title{
Determination of Galaxolide (HHCB) and Tonalide (AHTN) by Solid Phase Extraction and Gas Chromatography (SPE-GC)
}

\author{
Ying Xu ${ }^{1}$, Zhengwei Zhou ${ }^{1,}{ }^{*}$ iD \\ 1 School of Environmental and Safety Engineering, Changzhou University, Changzhou 213164, P. R. China \\ * Correspondence zwzhou@cczu.edu.cn (Z.Z.);
}

Scopus Author ID 57226874137

Received: 5.08.2021; Revised: 27.08.2021; Accepted: 29.08.2021; Published: 4.09.2021

\begin{abstract}
Galaxolide (HHCB) and tonalide (AHTN), two popular synthetic musk compounds, have been widely detected in the environment, which would pose a potential hazard to the ecosystem. To develop a robust analytical methodology for such emerging micropollutants is very important to investigate their presence and transformation in water. In this study, an analytical process of solid-phase extraction (SPE) coupled with gas chromatography (GC) was developed to determine trace levels of HHCB and AHTN in water. Specifically, the target compounds in test solutions were firstly extracted by SPE cartridges, followed by an eluting and redissolving process. Then, the enriched solutions were analyzed using a GC system with a flame ionization detector (FID). This analytical process demonstrated good recoveries for both compounds with mean recoveries of $104.7 \pm 5.1 \%$ and $102.9 \pm$ $4.8 \%$ for HHCB and AHTN, respectively. Above all, the SPE-GC analytical process proposed in this study provides a reliable method to assess the performance of future treatment trials.
\end{abstract}

Keywords: galaxolide (HHCB); tonalide (AHTN); solid phase extraction (SPE); gas chromatography (GC).

(C) 2021 by the authors. This article is an open-access article distributed under the terms and conditions of the Creative Commons Attribution (CC BY) license (https://creativecommons.org/licenses/by/4.0/).

\section{Introduction}

Due to their low price and long-lasting flavor, synthetic musks have been widely used as fragrance ingredients in daily necessities, such as detergent, perfume, air freshener, and cosmetics [1-4]. Of the synthetic musk compounds, galaxolide (HHCB) and tonalide (AHTN) are the largest volume products, accounting for over $90 \%$ of the global market [5]. Due to their widespread use, synthetic musks are discharged after use via domestic wastewater and enter the wastewater treatment plants (WWTPs), and most of them are expected to be released into the environment since the elimination of synthetic musks in WWTPs is not efficient [6-9]. Therefore, research on their occurrence, transportation, toxicity, and treatment has become very popular in recent years [10-15]. In this study, HHCB and AHTN (Table 1) in simulating water samples were detected simultaneously by a simple solid-phase extraction (SPE) and gas chromatography (GC) method, which would offer a validated analytical method for the further performance assessment of HHCB and AHTN removal in treatment trials. 
Table 1. Information about HHCB and AHTN.

\begin{tabular}{l|l|l|l|l|} 
Name & CAS NO & $\log \mathbf{P}$ & Chemical structure & Ref. \\
\hline HHCB & $1222-05-5$ & 5.3 \\
\hline AHTN & $1506-02-1$ & 5.4
\end{tabular}

\section{Materials and Methods}

Analytical grade HHCB and AHTN standard solutions (10 mg L $\left.\mathrm{L}^{-1}, 1 \mathrm{~mL}\right)$ were purchased from J\&K Chemical (Germany). Phenylethyl propionate, which was utilized as the internal standard, was also obtained from J\&K Chemical (Germany). All other chemicals and reagents were purchased from Sinopharm (China) and were applied without further purification. In order to investigate the accuracy and precision of the proposed SPE-GC analytical method, HHCB and AHTN test solutions of various concentrations were prepared and subjected to all the analytical processes. The concentrations of each target compound were set at six levels: $2,4,8,10,12$, and $16 \mu \mathrm{g} \mathrm{L}^{-1}$. The concentration of internal standard was 200 $\mu \mathrm{g} \mathrm{L}^{-1}$. Five parallel samples were prepared for each concentration.

Test solutions were filtered using $0.45 \mu \mathrm{m}$ membrane filter (Anpel, China) and then subjected to SPE extraction. The SPE cartridges utilized in this study were Generik H2P 60 $\mathrm{mg} / 3 \mathrm{~mL}$ tubes (Sepax Technologies, China). For all test solutions, $50 \mathrm{~mL}$ solution was used for the SPE extractions with an automatic SPE432-EVA32 SPE working station (Pretyco, China). Generally, the extraction protocol was: (1) conditioning: $10 \mathrm{~mL}$ methanol; (2) equilibrating: $6 \mathrm{~mL}$ water $+6 \mathrm{~mL}$ acidified water $(\mathrm{HCl} \mathrm{0.1 \%} \mathrm{v/v);} \mathrm{(3)} \mathrm{loading} \mathrm{samples:} 50 \mathrm{~mL}$ of test solutions were extracted at a flow rate of $5 \mathrm{~mL} \mathrm{~min}^{-1}$; (4) washing: $6 \mathrm{~mL}$ water at a flow rate of $3 \mathrm{~mL} \mathrm{~min}^{-1}$; and (5) elution: $5 \mathrm{~mL}$ methanol. The elutes were evaporated using a nitrogen blower (Pretyco, China) to dryness at $55^{\circ} \mathrm{C}$ under gentle nitrogen flow and then reconstituted to $1 \mathrm{~mL}$ by cyclohexane. The final enriched samples were filtered using $0.45 \mu \mathrm{m}$ nylon syringe filters (Anpel, China) and then subjected to further GC analysis.

An Agilent 7820A GC system (Agilent, USA) with a flame ionization detector (FID) was employed to measure the target compounds. Target compounds were separated by an Agilent HP-88 capillary column ( $30 \mathrm{~m} \times 0.25 \mathrm{~mm}$ i.d., $0.25 \mu \mathrm{m}$ film thickness, Agilent, USA) with nitrogen as carrier gas at a flow rate of $1 \mathrm{~mL} / \mathrm{min}$. The oven temperature program was as follows: initial temperature of $120^{\circ} \mathrm{C}$ (held for $4 \mathrm{~min}$ ), then increased to $320{ }^{\circ} \mathrm{C}$ at a rate of 15 ${ }^{\circ} \mathrm{C} \mathrm{min}^{-1}$, and held at $320^{\circ} \mathrm{C}$ for $3 \mathrm{~min}$. The injection volume was set as $1 \mu \mathrm{L}$.

\section{Results and Discussion}

HHCB, AHTN, and the standard internal chemical were separated in the GC using the HP-88 capillary column. As shown in Figure 1, the gradient increase of the column temperature led to a clear separation of three chemicals within $13 \mathrm{~min}$. Phenylethyl propionate came out firstly from the column with a retention time of $7.036 \mathrm{~min}$. AHTN was eluted secondly at $11.568 \mathrm{~min}$ and followed by HHCB at $12.069 \mathrm{~min}$. 


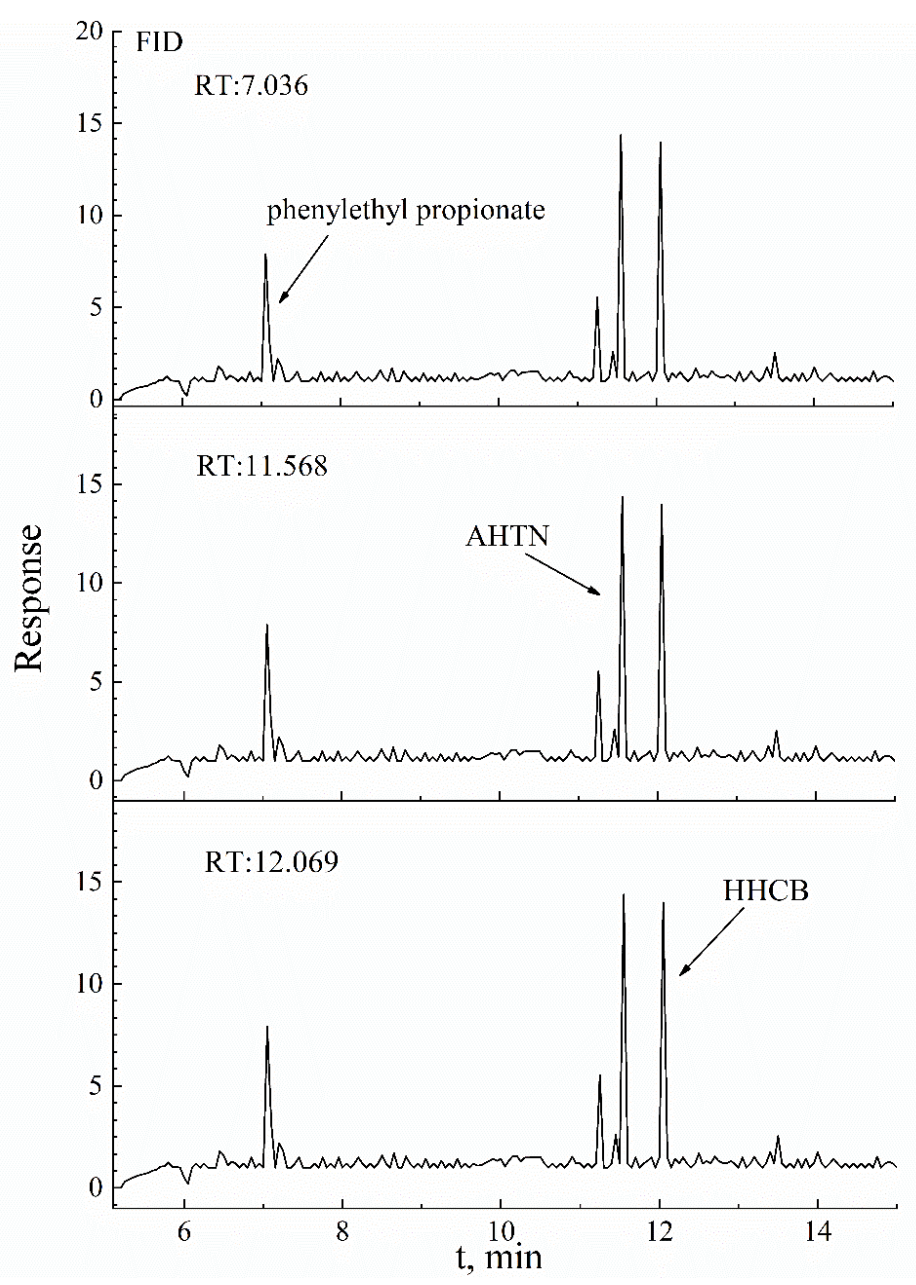

Figure 1. GC chromatographs of HHCB, AHTN and internal standard (HHCB, AHTN:0.8 mg L ${ }^{-1}$; internal standard: $0.2 \mathrm{mg} \mathrm{L}^{-1}$ ).

As shown in Table 2, the calibration curves of HHCB and AHTN covering $0.1 \sim 1 \mathrm{mg}$ $\mathrm{L}^{-1}$ demonstrated good coefficients of correlation $\left(r^{2}>0.99\right)$. The HHCB and AHTN spiked concentrations in test solutions were quantified according to their specific linear regression equations. The calculated recoveries of each sample were obtained based on detected and spiked quantities of target compounds in the test solutions and are presented in Table 3. The results demonstrated good recoveries of HHCB and AHTN of various initial concentrations, with overall recoveries $104.7 \pm 5.1 \%$ and $102.9 \pm 4.8 \%$, respectively.

Table 2. Calibrations curves of HHCB and AHTN.

\begin{tabular}{|c|c|c|c|c|}
\hline $\begin{array}{l}\text { Chemical } \\
\text { compound }\end{array}$ & $\begin{array}{c}\text { Equation of linear } \\
\text { regression }\end{array}$ & $\begin{array}{c}\text { Correlation } \\
\text { coefficient }\end{array}$ & Linear range $\left(\mathrm{mg} \mathrm{L}^{-1}\right)$ & LOD $\left(\mathrm{mg} \mathrm{L}^{-1}\right)$ \\
\hline HHCB & $y=0.2215 x+0.0282$ & $\mathrm{R}^{2}=0.9956$ & \multirow{2}{*}{$0.1 \sim 1$} & 0.07 \\
\hline AHTN & $\mathrm{y}=0.1759 \mathrm{x}+0.0038$ & $\mathrm{R}^{2}=0.9991$ & & 0.08 \\
\hline
\end{tabular}

Table 3. Recoveries of HHCB and AHTN with various concentrations.

\begin{tabular}{l|c|c} 
Test solutions & HHCB & AHTN \\
\hline $2 \mu \mathrm{g} \mathrm{L}^{-1}$ & $107.1 \pm 5.3 \%$ & $103.1 \pm 3.8 \%$ \\
\hline $4 \mu \mathrm{g} \mathrm{L}^{-1}$ & $103.4 \pm 3.7 \%$ & $102.2 \pm 2.1 \%$ \\
\hline $8 \mu \mathrm{g} \mathrm{L}^{-1}$ & $103.3 \pm 3.8 \%$ & $104.1 \pm 5.3 \%$ \\
\hline $10 \mu \mathrm{g} \mathrm{L}^{-1}$ & $106.0 \pm 1.8 \%$ & $101.8 \pm 6.1 \%$ \\
\hline $12 \mu \mathrm{g} \mathrm{L}^{-1}$ & $108.9 \pm 7.9 \%$ & $103.3 \pm 4.9 \%$ \\
\hline $16 \mu \mathrm{g} \mathrm{L}^{-1}$ & $99.3 \pm 7.8 \%$ & $102.7 \pm 6.7 \%$ \\
\hline Overall recovery & $104.7 \pm 5.1 \%$ & $102.9 \pm 4.8 \%$
\end{tabular}


Table 4. Comparison of recoveries with other analytical methods.

\begin{tabular}{|c|c|c|c|c|}
\hline \multirow{2}{*}{ Method } & \multirow{2}{*}{$\begin{array}{l}\text { Water } \\
\text { matrix }\end{array}$} & \multicolumn{2}{|l|}{ Recovery, \% } & \multirow{2}{*}{ Ref. } \\
\hline & & HHCB & AHTN & \\
\hline \multirow{4}{*}{$\begin{array}{l}\text { Liquid-liquid microextraction (LLME) }+ \\
\text { GC-MS/MS }\end{array}$} & Wastewater & $97 \pm 3 \sim 102 \pm 11$ & $71 \pm 7 \sim 99 \pm 3$ & \multirow{4}{*}[17]{} \\
\hline & Tap water & $75 \pm 2 \sim 97 \pm 14$ & $91 \pm 3 \sim 106 \pm 12$ & \\
\hline & Sea water & $96 \pm 5 \sim 107 \pm 8$ & $92 \pm 11 \sim 101 \pm 4$ & \\
\hline & River water & $101 \pm 15 \sim 105 \pm 3$ & $83 \pm 3 \sim 96 \pm 7$ & \\
\hline \multirow{4}{*}{$\begin{array}{l}\text { Liquid-liquid microextraction (LLME) }+ \\
\text { GC-MS/MS }\end{array}$} & Wastewater & $88 \pm 7 \sim 113 \pm 5$ & $84 \pm 4 \sim 114 \pm 6$ & \multirow{4}{*}[18]{} \\
\hline & Tap water & $93 \pm 4 \sim 106 \pm 1$ & $91 \pm 3 \sim 106 \pm 1$ & \\
\hline & Sea water & $91 \pm 2 \sim 115 \pm 1$ & $102 \pm 3 \sim 112 \pm 4$ & \\
\hline & River water & $86 \pm 4 \sim 117 \pm 4$ & $85 \pm 5 \sim 118 \pm 9$ & \\
\hline $\begin{array}{l}\text { Solid-phase microextraction (SPME) + GC- } \\
\text { MS/MS }\end{array}$ & River water & $102 \pm 1$ & $95.4 \pm 7.1$ & [19] \\
\hline SPE+GC-LID & Pure water & $99.3 \pm 7.8 \sim 108.9 \pm 7.9$ & $101.8 \pm 6.1 \sim 104.1 \pm 5.3$ & This study \\
\hline
\end{tabular}

In comparison with other studies (Table 4), the established SPE-GC analytical methods show good recoveries of HHCB and AHTN, which is reliable for determining residual concentrations of HHCB and AHTN in test solutions.

\section{Conclusions}

An SPE-GC analytical process was established in this study to detect HHCB and AHTN in test solutions with good recoveries, which were $104.7 \pm 5.1 \%$ and $102.9 \pm 4.8 \%$, respectively. It offers a validated analytical method for the further assessment of HHCB and AHTN removal in test solutions.

\section{Funding}

This research was funded by the National Natural Science Foundation of China, grant number 51808060 .

\section{Acknowledgments}

The authors would like to thank the technical support from the engineers of the Analytical Centre of the School of Environmental and Safety Engineering, Changzhou University.

\section{Conflicts of Interest}

The authors declare no conflict of interest.

\section{References}

1. Wong, F.; Robson, M.; Melymuk, L.; Shunthirasingham, C.; Alexandrou, N.; Shoeib, M.; Luk, E.; Helm, P.; Diamond, Miriam L.; Hung, H. Urban sources of synthetic musk compounds to the environment. Environmental Science: Processes \& Impacts 2019, 21, 74-88, https://doi.org/10.1039/c8em00341f.

2. Patel, S.; Homaei, A.; Sharifian, S. Need of the hour: to raise awareness on vicious fragrances and synthetic musks. Environment, Development and Sustainability 2021, 23, 4764-4781, https://doi.org/10.1007/s10668020-00829-4.

3. Martín-Pozo, L.; Gómez-Regalado, M.d.C.; Moscoso-Ruiz, I.; Zafra-Gómez, A. Analytical methods for the determination of endocrine disrupting chemicals in cosmetics and personal care products: A review. Talanta 2021, 234, https://doi.org/10.1016/J.TALANTA.2021.122642.

4. Katuri, G.P.; Fan, X.; Siddique, S.; Kubwabo, C.; Kosarac, I.; Harris, S.A.; Foster, W.G. A Selective and Sensitive Gas Chromatography-Tandem Mass Spectrometry Method for Quantitation of Synthetic Musks in Human Serum. Journal of AOAC International 2020, 103, 1461-1468, https://doi.org/10.1093/JAOACINT/QSAA051.

5. Clara, M.; Gans, O.; Windhofer, G.; Krenn, U.; Hartl, W.; Braun, K.; Scharf, S.; Scheffknecht, C. Occurrence of polycyclic musks in wastewater and receiving water bodies and fate during wastewater treatment. Chemosphere 2011, 82, 1116-1123, https://doi.org/10.1016/j.chemosphere.2010.11.041. 
6. Homem, V.; Silva, J.A.; Ratola, N.; Santos, L.; Alves, A. Long lasting perfume - A review of synthetic musks in WWTPs. Journal of Environmental Management 2015, 149, 168-192, https://doi.org/10.1016/j.jenvman.2014.10.008.

7. Wei, W.; Wu, L.; Liu, X.; Chen, Z.; Hao, Q.; Wang, D.; Liu, Y.; Peng, L.; Ni, B.-J. How does synthetic musks affect methane production from the anaerobic digestion of waste activated sludge? Science of The Total Environment 2020, 713, https://doi.org/10.1016/j.scitotenv.2020.136594.

8. Celeiro, M.; Lamas, J.P.; Vila, M.; Garcia-Jares, C.; Homem, V.; Ratola, N.; Dagnac, T.; Llompart, M. Determination of multiclass personal care products in continental waters by solid-phase microextraction followed by gas chromatography-tandem mass spectrometry. Journal of Chromatography A 2019, 1607, https://doi.org/10.1016/j.chroma.2019.460398.

9. Fan, B.; Wang, X.; Li, J.; Gao, X.; Li, W.; Huang, Y.; Liu, Z. Deriving aquatic life criteria for galaxolide (HHCB) and ecological risk assessment. Science of The Total Environment 2019, 681, 488-496, https://doi.org/10.1016/j.scitotenv.2019.05.033.

10. Hong, J.-H.; Lee, J.-Y.; Ha, H.-J.; Lee, J.-H.; Oh, S.-R.; Lee, Y.-M.; Lee, M.-Y.; Zoh, K.-D. Occurrence and Sources of Synthetic Musk Fragrances in the Sewage Treatment Plants and the Han River, Korea. Water 2021, 13, https://doi.org/10.3390/W13040392.

11. Vimalkumar, K.; Nikhil, N.P.; Arun, E.; Mayilsamy, M.; Babu-Rajendran, R. Synthetic musks in surface water and fish from the rivers in India: Seasonal distribution and toxicological risk assessment. Journal of Hazardous Materials 2021, 414, https://doi.org/10.1016/J.JHAZMAT.2021.125558.

12. Lyu, Y.; Ren, S.; Zhong, F.; Han, X.; He, Y.; Tang, Z. Synthetic musk fragrances in sediments from a subtropical river-lake system in eastern China: occurrences, profiles, and ecological risks. Environmental Science and Pollution Research 2021, 28, 14597-14606, https://doi.org/10.1007/S11356-020-11486-5.

13. Balci, E.; Genisoglu, M.; Sofuoglu, S.C.; Sofuoglu, A. Indoor air partitioning of Synthetic Musk Compounds: Gas, particulate matter, house dust, and window film. Science of The Total Environment 2020, 729 , https://doi.org/10.1016/j.scitotenv.2020.138798.

14. Sousa, S.; Pestana, D.; Faria, G.; Vasconcelos, F.; Delerue-Matos, C.; Calhau, C.; Domingues, V.F. Method development for the determination of Synthetic Musks and Organophosphorus Pesticides in Human Adipose Tissue. Journal of Pharmaceutical and Biomedical Analysis 2020, 191, https://doi.org/10.1016/j.jpba.2020.113598.

15. Ding, T.; Li, W.; Cai, M.; Jia, X.; Yang, M.; Yang, B.; Li, J. Algal toxicity, accumulation and metabolic pathways of galaxolide. Journal of Hazardous Materials 2020, 384 , https://doi.org/10.1016/j.jhazmat.2019.121360.

16. Fan, M.; Liu, Z.; Dyer, S.; Xia, P.; Zhang, X. Environmental risk assessment of polycyclic musks HHCB and AHTN in consumer product chemicals in China. Science of The Total Environment 2017, 599-600, 771-779, https://doi.org/10.1016/j.scitotenv.2017.05.036.

17. Homem, V.; Alves, A.; Alves, A.; Santos, L. Ultrasound-assisted dispersive liquid-liquid microextraction for the determination of synthetic musk fragrances in aqueous matrices by gas chromatography-mass spectrometry. Talanta 2016, 148, 84-93, https://doi.org/10.1016/j.talanta.2015.10.049.

18. Ramos, S.; Homem, V.; Santos, L. Simultaneous determination of synthetic musks and UV-filters in water matrices by dispersive liquid-liquid microextraction followed by gas chromatography tandem massspectrometry. Journal of Chromatography A $2019, \quad$ 1590, https://doi.org/10.1016/j.chroma.2019.01.013.

19. Celeiro, M.; Lamas, J.P.; Vila, M.; Garcia-Jares, C.; Homem, V.; Ratola, N.; Dagnac, T.; Llompart, M. Determination of multiclass personal care products in continental waters by solid-phase microextraction followed by gas chromatography-tandem mass spectrometry. Journal of Chromatography A 2019, 1607, https://doi.org/10.1016/j.chroma.2019.460398. 